\title{
The use of non-human primates as animal models for the study of hepatitis viruses
}

C.L. Vitral ${ }^{1,2}$,

C.F.T. Yoshida ${ }^{1}$ and A.M.C. Gaspar ${ }^{1}$

\author{
1Departamento de Virologia, Instituto O swaldo Cruz, FIOCRUZ, \\ Rio de Janeiro, RJ, Brasil \\ 2Departamento de Microbiologia e Parasitologia, \\ Universidade Federal Fluminense, Niterói, RJ, Brasil
}

\section{Correspondence \\ C.L. Vitral \\ Departamento de Virologia \\ IOC/FIOCRUZ \\ Av. Brasil, 4365 \\ 21040-360 Rio de Janeiro, RJ \\ Brasil \\ Fax: 55 (021) 270-6397 \\ Research supported by FAPERJ and CNPq.}

Received November 14, 1997

Accepted April 22, 1998

\begin{abstract}
Hepatitis viruses belong to different families and have in common a striking hepatotropism and restrictions for propagation in cell culture. The transmissibility of hepatitis is in great part limited to non-human primates. Enterically transmitted hepatitis viruses (hepatitis A virus and hepatitis E virus) can induce hepatitis in a number of Old World and New World monkey species, while the host range of non-human primates susceptible to hepatitis viruses transmitted by the parenteral route (hepatitis $\mathrm{B}$ virus, hepatitis $\mathrm{C}$ virus and hepatitis delta virus) is restricted to few species of Old World monkeys, especially the chimpanzee. Experimental studies on non-human primates have provided an invaluable source of information regarding the biology and pathogenesis of these viruses, and represent a still indispensable tool for vaccine and drug testing.
\end{abstract}

Key words

- Hepatitis viruses

- Non-human primates

- Animal model

- Experimental infection

\section{Introduction}

Viral hepatitis represents a global public health problem. There are at least five viruses that classically cause hepatitis in man: hepatitis A virus (HAV) and hepatitis E virus (HEV) transmitted by the fecal-oral route and causing only acute, self-limited infections, and hepatitis B virus (HBV), hepatitis $\mathrm{C}$ virus (HCV) and hepatitis delta virus (HDV) transmitted by blood and other body fluids with the possibility of persistence and development of liver cirrhosis and primary hepatocellular carcinoma (HCC). The recently identified hepatitis $\mathrm{G}$ virus (HGV) has not been definitively associated with any disease (1). These viruses belong to different families and have in common a striking hepatotropism and substantial restrictions for propagation in conventional cell cultures. HAV may be an exception to this rule in that it is amenable to propagation in several types of primate cell cultures (2). However, except for some fast-growing HAV isolates (3), its replication is remarkably slow, and nearly always non-cytopathic. For this reason, transmission of hepatitis viruses to non-human primates, the only available animal model, is an invaluable tool for the propagation of these viruses, as well as for studies of their biology and pathogenesis.

\section{Historical aspects}

Attempts to transmit human hepatitis to non-human primates were generally unsuc- 
cessful until the 1960s. Prior to this period, no approach was available to determine the infectivity of the inoculum or the previous immune status of the animals (4). The interest in non-human primates as models for hepatitis was stimulated when natural transmission of hepatitis from primates to man was reported at a U.S. Air Force base (5). In 1962, Deinhardt et al. (6) described biochemical and histopathologic changes during an episode of mild hepatitis in chimpanzees inoculated with acute-phase serum or feces from patients with a disease that had the epidemiologic characteristics of hepatitis A. In 1967, the same group reported transmission of an agent of hepatitis to marmosets using acute-phase serum from a surgeon (initials GB) with hepatitis (7). The latter results were contested by the evidence that hepatitis in the marmosets may have resulted from the reactivation of a latent marmoset hepatitis agent (8). Transmission of HAV was confirmed by inoculation of marmosets and chimpanzees with acutephase sera and feces from HAV-infected human volunteers $(9,10)$. Soon after these events, the discovery of Australia antigen (or HBsAg) (11) and the identification of HAV (12) were reported, leading to the development of the first serological assays for hepatitis A and hepatitis B.

Subsequently, it was realized that many epidemics of enterically transmitted hepatitis were not caused by HAV and that most cases of posttransfusion hepatitis were due to an agent other than HBV. These cases were termed enterically and parenterally transmitted non-A, non-B hepatitis (ETNANBH and PT-NANBH, respectively). Primate models for experimental infections with the agent of PT-NANBH were developed in the late 1970s with the demonstration that specimens from patients infected with non-A, non-B hepatitis readily produced hepatitis in chimpanzees (13-15). The causative agent of PT-NANBH was only identified in 1989, when the application of recom- binant DNA technology made possible the identification of hepatitis $\mathrm{C}$ virus (HCV) specific nucleic acid (16), and the development of the first specific serologic assay (17). Critical to the success of this approach was the availability of large volumes $(2,500$ $\mathrm{ml}$ ) of high-titer chimpanzee plasma from which sufficient cDNA could be produced. $\mathrm{HCV}$ represents the predominant cause of transfusion-associated hepatitis around the world as well as a major cause of liver cirrhosis and HCC (18).

Transmission of ET-NANBH to non-human primates was first reported in 1983 by Balayan et al. (19), who successfully inoculated intravenously $(\mathrm{iv})$ a $10 \%-\mathrm{w} / \mathrm{v}$ stool suspension from a human volunteer that was positive by immune electron microscopy for virus-like particles $27-30 \mathrm{~nm}$ in diameter. Transmission to monkeys remained the only means of studying ET-NANBH until 1990, when Reyes et al. (20) cloned and sequenced part of the viral genome. The complete sequence of the viral genome is now known and the agent, renamed hepatitis $\mathrm{E}$ virus (HEV), is considered to be the major cause of sporadic hepatitis in Asia, Africa and India (21).

The identification of HDV occurred in the mid-70s with the detection of a previously unrecognized nuclear antigen in hepatocyte nuclei of an Italian patient with chronic hepatitis B (22). The antigen, called delta antigen (HDAg), was initially believed to be a previously unnoticed hepatitis B-specific antigen. Transmission experiments in chimpanzees were published in 1980 (23). Chimpanzees were the only animals known at that time to be susceptible to HBV infection, and supposedly permissive to HDAg expression. Those studies confirmed that HDAg was a component of a defective transmissible pathogen that required coinfection with HBV for its replication. Epidemiologic studies showed that hepatitis associated with expression of HDAg was highly endemic in Italy and among several populations from South Ame- 
rica, including Brazil (24). By 1983, the HDAg was designated as a distinct hepatitis virus, the hepatitis D or delta virus (HDV) (25).

After reliable immunoassays and molecular probes became available for the detection of $\mathrm{HCV}$ and $\mathrm{HEV}$ infections, it was evident that $10-20 \%$ of non-A, non-B hepatitis cases were not caused by HCV or HEV. One of the first hepatitis agents to be transmitted to non-human primates originated from the serum of a surgeon (initials GB) obtained on the third day of jaundice (7). Tamarins inoculated with serum from this patient developed hepatitis, as did tamarins inoculated in serial passage studies. The putative etiologic agent was called the GB agent. In 1995, Simons and co-workers (26) identified two viruses, GB virus A (GBV-A) and $G B$ virus $B(G B V-B)$ in the acute phase serum of a tamarin that developed hepatitis following inoculation with serum from the 11th tamarin passage of the GB agent. Both viruses were shown to be related to viruses of the family Flaviviridae, in particular to $\mathrm{HCV}$. However, the origin of these viruses remains unknown, and neither one has been detected in humans. Recently, Bukh and Apgar (27) analyzed sera from 98 wild-caught New World monkeys representing 10 different species, and found that many of these monkeys seem to be persistently infected with GBV-A. In 1996, a third virus named GB virus $\mathrm{C}$ (GBV-C) or hepatitis $\mathrm{G}$ virus (HGV), more closely related to GBV-A, was identified in humans by two research groups $(28,29)$. GBV-C and HGV share $86 \%$ of their nucleotide sequences and $96 \%$ of their deduced amino acid sequences, and are believed to be two isolates of the same virus. HGV was detected not only in patients with acute, chronic, and fulminant hepatitis, persons with history of blood transfusion, patients on hemodialysis, and intravenous drug users, but also in health blood donors (30). For this reason, HGV is not definitely associated with any disease (1).

\section{Transmission of hepatitis viruses to non-human primates}

Non-human primates have played an essential role in the understanding of the various forms of viral hepatitis. A different range of monkeys are susceptible to hepatitis viruses, as summarized in Table 1.

\section{Enterically transmitted hepatitis viruses}

\section{Hepatitis A virus (HAV)}

Experimental studies of HAV infection have been carried out in several non-human primates, including both Old World and New World monkeys, as listed in Table 1. We

Table 1 - Non-human primates used as animal models for studies on hepatitis virus infection.

HAV, Hepatitis A virus; HBV, hepatitis B virus; HCV, hepatitis C virus; HDV, hepatitis D virus; $\mathrm{HEV}$, hepatitis $\mathrm{E}$ virus.

\begin{tabular}{|c|c|c|c|}
\hline \multirow[t]{2}{*}{ Hepatitis virus } & \multicolumn{2}{|c|}{ Non-human primates } & \multirow[t]{2}{*}{ References } \\
\hline & Common names & Species & \\
\hline \multirow[t]{7}{*}{ HAV } & Chimpanzee & Pan troglodytes & $10,46,51,54$ \\
\hline & Rhesus monkey & Macaca mulatta & 36 \\
\hline & African green monkey & Cercopithecus aethiops & 46 \\
\hline & Owl monkey & Aotus trivirgatus & $39,41,52$ \\
\hline & Tamarin & Saguinus sp & $7,9,42,47,53$ \\
\hline & Marmoset & Callithrix jacchus & $33,34,38$ \\
\hline & Squirrel monkey & Saimiri sciureus & 31,35 \\
\hline \multirow[t]{4}{*}{ HBV } & Chimpanzee & Pan troglodytes & $82,91,93,94$ \\
\hline & Baboon & Papio sp & 77 \\
\hline & Tree shrew & Tupaia sp & 83 \\
\hline & & Macaca assamensis & 84 \\
\hline \multirow[t]{2}{*}{$\mathrm{HCV}$} & Chimpanzee & Pan troglodytes & $\begin{array}{l}13-15,97,102 \\
109-112\end{array}$ \\
\hline & Rhesus monkey & Macaca mulatta & 120,121 \\
\hline HDV & Chimpanzee & Pan troglodytes & $23,123,125,129$ \\
\hline \multirow[t]{6}{*}{ HEV } & Chimpanzee & Pan troglodytes & 61,72 \\
\hline & Rhesus monkey & Macaca mulatta & $61,65-68$ \\
\hline & African green monkey & Cercopithecus aethiops & 61 \\
\hline & Owl monkey & Aotus trivirgatus & $60,61,72$ \\
\hline & Tamarin & Saguinus sp & $59,61,72$ \\
\hline & Squirrel monkey & Saimiri sciureus & 61 \\
\hline
\end{tabular}


failed to induce hepatitis A infection in squirrel monkeys (Saimiri sciureus) with a Brazilian HAV isolate (HAF-203) $(2,3)$ by the intragastric route, but animals inoculated by the $i v$ route were efficiently infected (31), in agreement with previous observations (32). Monkeys inoculated with HAV by the intragastric route did not develop signs of hepatitis but seroconverted, and viral RNA was demonstrated in feces by RT-PCR (Vitral CL, unpublished results). HAF-203 has produced infection following intragastric inoculation in the marmoset Callithrix jacchus (33,34).

HAV-induced disease in non-human primates resembles human disease, but is usually milder, or subclinical, followed by complete recovery. Similar to human hepatitis, relapsing courses of hepatitis A have also been reported in experimentally infected monkeys (35-37). After infection by the intragastric or $i v$ route, HAV or viral antigen is first detected in hepatocytes, then in serum, bile and feces. These events precede liver injury, which appears concomitantly with the seroconversion.

C. jacchus has been the non-human primate of choice in our experimental infection studies with HAV because it is readly available, easy to handle and highly susceptible to HAV $(33,34,38)$. In this model, several pathological aspects of HAV infection can be analyzed, such as the mechanism involved in liver cell injury and the possibility of extrahepatic sites of HAV replication. After intragastric or $i v$ infection, HAV antigen (HAVAg) is detected in feces and liver in the absence of detectable alanine aminotransferase (ALT) elevation or hepatocellular changes $(33,34,38)$. The diagnosis of enhanced hepatic lesions coincides with seroconversion and expression of interleukin 6 and inducible nitric oxide synthase, while HAVAg was not detected in feces and liver, or was present in small amounts (Pinto MA, personal communication). These findings suggest an immune-mediated mech- anism of hepatic injury rather than a direct cytopathic effect, a hypothesis supported by other experimental studies $(39,40)$. How the virus reaches the liver and the existence of non-hepatic sites of primary viral replication are matters as yet undefined. It has been assumed that after ingestion HAV reaches the liver where it replicates before being excreted through the bile into the intestine, since its detection in the intestinal mucosa or any other organ except the liver has been inconsistent (40-43). Our own experiments with immunohistochemistry revealed extrahepatic HAVAg in the kidney, spleens, lymph nodes and small intestine $(33,38)$. However, this may represent humoral immune clearance rather than active viral replication, as also suggested by others $(43,44)$.

Spontaneous outbreaks of hepatitis A have been reported in captive non-human primates including owl monkeys, cynomolgus monkeys, rhesus monkeys, stump-tailed and African green monkeys (45). The presence of anti-HAV antibody in the sera of newly captured monkeys of these species shows that infection may also spread in their natural habitat. HAV strains have been recovered from several of these species in captivity, but it is still unknown whether these viruses were acquired from humans (45). Preliminary molecular analysis of some of these strains suggests that they are sufficiently different from known human strains to be considered as separate simian viruses. Infection of monkeys with such strains results in hepatitis and at least partial protection against challenge with human HAV strains. Nevertheless, recent data have shown that the AGM-27 strain isolated from an African green monkey failed to produce hepatitis in chimpanzees (46), but elicited protective anti-HAV responses, suggesting that it may be naturally attenuated for higher primates.

The production of biological specimens represents one of the applications of nonhuman primates in experimental infections 
with HAV. Feces can be collected at the end of the incubation period, representing the most abundant and accessible source of HAV, and liver biopsies can also be performed during the acute phase of infection. Moreover, development of specific antibodies can be monitored for the production of hyperimmune sera useful for diagnostic purposes. Non-human primates have also been useful in the titration of the infectivity of HAV isolates $(33,34)$ and for in vivo intrahepatic cDNA transfection $(47,48)$. They also represent a valuable tool in the analysis of obscure pathogenetic aspects of HAV infection $(33,34,39-42,44,49-53)$, and for testing the safety and immunogenicity of candidate HAV vaccines (54-58). A formalin-inactivated hepatitis A vaccine was recently licensed for human use.

\section{Hepatitis E virus (HEV)}

Several species of non-human primates are susceptible to experimental HEV infection, as shown in Table 1. The most useful of them have been cynomolgus and rhesus macaques (59-67). HEV was transmitted to primates by the $i v(61,63,67)$ and oral routes (68), but the latter was shown to be less efficacious (69).

The analysis of clinical and pathologic features in experimentally infected primates has contributed to a better understanding of the natural history of HEV infection, which is similar to that in man. Clinically overt hepatitis is observed in only half of the inoculated animals. The incubation period to peak liver enzyme levels is generally 3 to 8 weeks (59-61). The overall course of the infection appears to follow a rather predictable pattern, with detection of HEV antigen (HEVAg) in hepatocytes, virus excretion in the feces and viremia during the incubation period and early acute phase of disease (6264). Histopathologic changes in the liver parallel the seroconversion and biochemical evidence of hepatitis, with resolution in all cases. In addition, negative strands of HEV RNA replicative intermediates were detected in the livers of infected rhesus monkeys, which constitutes direct evidence of HEV replication in this organ (65). The virulence of HEV does not seem to be increased by serial passages in monkeys (70). Naturally acquired anti-HEV has been detected in wildcaught cynomolgus monkeys and captive rhesus monkeys (71), suggesting that zoonotic spread of HEV may occur.

The primate model has helped elucidating aspects of the pathogenesis of HEV infection. First of all, the mechanism(s) by which HEV reaches the liver from the intestinal tract is unknown. The virus was found in the cytoplasm of hepatocytes, bile and feces during the second or third week after inoculation and prior to, or concurrently with the onset of ALT elevation and liver histopathologic changes $(60,63,64)$. This suggests that HEV may be released from hepatocytes into the bile before the peak of morphologic changes in the liver, during the highly replicative initial phase of infection. The involvement of the immune system in liver injury after HEV infection has also been unclear. The onset of ALT elevations and liver histopathologic changes generally corresponds to the rise of serum anti-HEV and decrease of HEVAg in hepatocytes. Infiltrating lymphocytes in the liver of HEV-infected cynomolgus were found to have a cytotoxic/suppressive phenotype (72).

Human HEV infection causes substantial mortality due to fulminant hepatitis among pregnant women in some developing countries. The mechanism for this is completely undefined. Pregnant rhesus monkeys inoculated intravenously with a prototype HEV strain (SAR-55) at different stages of pregnancy did not develop disease of increased severity (67).

Non-human primates have been used for testing the immunogenicity of recombinant HEV proteins expressed in insect cells (61), and for titration of infectivity of prototype 
strains of HEV (69). Another important application of primate studies was to find evidence of immune cross-protection between different isolates of HEV, which have been shown to be closely related at the genetic level (66). This fact may greatly facilitate the development of a hepatitis E vaccine. At present, there are no commercially available vaccines for the prevention of hepatitis $\mathrm{E}$. Nevertheless, preliminary attempts to protect primates against hepatitis $\mathrm{E}$ by vaccination with recombinant HEV-derived proteins have produced encouraging results $(73,74)$. Experimental studies in primates also suggest that passively acquired anti-HEV modifies but does not prevent HEV infection (75).

\section{Parenterally transmitted hepatitis viruses}

\section{Hepatitis B virus (HBV)}

The only non-human primate that can develop productive HBV infection is the chimpanzee, which has served as the model for the study HBV infection for over 20 years. Experimental infections of gibbons, woolly monkeys, tamarins and other primate species were generally unsatisfactory. There has been uncertainty about whether baboons are susceptible to HBV infection since seropositivity for anti-HBs among baboons was found in a serologic survey of primate sera (76). Baboons were also used as an animal model for the evaluation of the effect of adjuvant MF50 (Chiron) on the immunogenicity of recombinant hepatitis $B$ vaccine (77). In disagreement with this, Michaels et al. (78) failed to demonstrate even minimal viral replication during a 6-month follow-up using a highly sensitive PCR assay in two HBV-infected baboons, which is in accordance with previous observations by Deinhardt (4). The resistence of baboons to HBV infection is of great interest for treatment strategies involving the use of liver xenotransplantation in patients suffering from end-stage liver disease secondary to chronic
HBV infection.

The immunobiology of HBV infection in chimpanzees is similar to that observed in humans, except that the disease is generally less severe $(79,80)$. After the incubation period of 4-10 weeks, the disease can be monitored by the elevation in liver enzymes, histopathological changes in liver tissue and the evolution of HBV markers (HBsAg, anti$\mathrm{HBc}$, anti-HBs and HBV-DNA). HBcAg and HBsAg can be demonstrated in the hepatocytes of acute and chronically infected chimpanzees by immunohistochemistry.

HBsAg antigenemia can persist with progression to chronic infection, although substantially different from that observed in humans from both virological and pathological standpoints. Moreover, HCC was only rarely observed among chimpanzees infected with $\operatorname{HBV}(81,82)$. These facts, coupled with the severe limitation of chimpanzee availability, have led to the search for a more readily available animal for the investigation of the involvement of HBV infection in the etiology of HCC. Tree shrews, considered to be the lowest order of non-human primates, were successfully infected after inoculation with human serum positive for HBV (83). Infections were passed successfully through five generations and could be prevented by immunization with hepatitis $B$ vaccine. It remains to be known if tree shrews can develop chronic HBV infections and HCC. In another study, HBV was serially passaged in Macaca arssamensis, and 1 out of 7 animals developed HCC 2.5 years after inoculation (84). In addition, non-primate laboratory animals, such as the woodchuck, Pekin duck, ground squirrel, and transgenic mouse have replaced the chimpanzee in many instances (85). Although more distant from man than the chimpanzee, the eastern woodchuck (Marmota monax) is readily available, easy to handle and maintain, and much cheaper than the chimpanzee model (86). It is naturally infected with woodchuck hepatitis virus (WHV), another member of the 
family Hepadnaviridae, closely related to HBV.

Different hepatitis B vaccines have been evaluated for safety and potential for inducing protective immunity in non-human primates, including subunit HBV vaccines (plasma-derived subviral particles and recombinant subunit proteins), and, more recently, DNA vaccines (87-89). The latter methodology was shown to induce anti-HBs serum levels in chimpanzees comparable to those induced by recombinant subunit vaccines (89). Non-human primates are also used for the evaluation of neutralizing activity of hepatitis B immune globulin and antiHBs monoclonal antibodies (90-92), and in the investigation of the effect of different adjuvants on the immunogenicity of hepatitis $\mathrm{B}$ vaccine (77). Other applications are the study of the infectivity and pathogenicity of HBV strains including HBV genetic variants $(93,94)$, and the infectivity titration of HBV strains $(94,95)$.

\section{Hepatitis C virus (HCV)}

Due to the absence of an efficient in vitro system for HCV propagation, progress in the research of HCV biology depends almost entirely on infection studies carried out in chimpanzees, which represent the only reliable animal model for $\mathrm{HCV}$ infection. Almost all the knowledge of HCV biology was gained through experimental infection studies in this primate, mostly prior to the era of HCV molecular biology. A number of studies have provided information on the natural history of HCV infection in chimpanzees. A very early replicative phase is evident in these animals because hepatocytes are positive for viral RNA 1 to 2 days after experimental infection (96). Specific HCV antigens are also demonstrated in hepatocytes within days of inoculation (97). The paucity of positively stained cells suggests that the intracellular HCV load is small, which may be related to a slow viral replication rate and to the low level of HCV RNA typically found in serum. The possible existence of an extrahepatic site of $\mathrm{HCV}$ replication that could function as a reservoir of $\mathrm{HCV}$ remains controversial (98). Viremia detectable by PCR occurs within 1 week of infection (99-101) and a pattern of intermittent viremia is observed until the major peak of serum transaminases at 8 to 16 weeks postinfection $(102,103)$. In a recent study, it was shown that viremia levels in acute HCV infections in chimpanzees appeared to be at least 10 -fold higher when the infection progressed to resolution than when it progressed to chronicity. During chronic infections, the viral load fell rapidly after the acute phase and remained low. After 4 to 6 years, the viral load and liver enzymes increased again, suggesting reactivation of the infection (104). During the acute phase, seroconversion to one or more HCV antigens occurs concomitant with, or shortly after the peak of liver enzyme activity, but the antibody specificity patterns do not predict progression to chronicity $(100,101)$. As in humans, HCV infection does not resolve in most animals; prospective studies indicate that 50 to $70 \%$ have persistent or intermittent viremia for at least 6 months after inoculation with $\mathrm{HCV}$ $(102,103)$. A possible HCV-associated HCC was reported in one chimpanzee (105). The liver of viremic chimpanzees presented HCVspecific CD8+ cytotoxic T lymphocytes (CTLs) which lysed target cells expressing viral proteins (106). Anti-viral CTL are detectable in the liver during the acute phase of the disease, but are not sufficient to prevent the establishment of a persistent HCV infection (106). Using the chimpanzee model, it was shown that CTL escape mutants can be selected with an enhanced ability to persist in the host (107). The hypervariable region 1 (HVR 1) of the E2 protein changes continuously in hosts with chronic HCV infection, resulting in a quasispecies nature $(108,109)$. A close relationship was found between sequence variation in the $\mathrm{E} 2$ region, but not the 
E1 region, and specific humoral immune response to linear epitopes, which is in keeping with an immune-selection mechanism of viral evolution (104).

Although the development of a broadly reactive vaccine would be desirable for the control of hepatitis $\mathrm{C}$, the high degree of genetic heterogeneity of $\mathrm{HCV}$ raises concerns about its feasibility. Studies in the chimpanzee model revealed that there was no cross-protection between different inocula. In fact, a second episode of hepatitis occurred even when the subsequent challenge was done with the same virus as used for inoculation $(110,111)$. Chimpanzees have been protected against experimental challenge with $\mathrm{HCV}$ by prior vaccination with recombinant envelope glycoproteins (112), although doubts were expressed about the level of protection against heterologous $\mathrm{HCV}$ strains, the low dose and the short time for challenge after vaccination (113). Post-exposure treatment with hepatitis $\mathrm{C}$ immune globulin significantly prolonged the incubation period of acute hepatitis $\mathrm{C}$ in chimpanzees, albeit without preventing the development of hepatitis C (114). More recently, two research groups have succeeded in the construction of a stable full-length cDNA clone of HCV, whose infectivity was demonstrated by the injection of RNA transcripts into the liver of a chimpanzee, resulting in viral replication $(115,116)$.

Nowadays, chimpanzees are virtually unobtainable for research purposes and finding an alternative animal model constitutes a priority in this field. Studies with other nonhuman primates, most notably tamarin species (Saguinus mystax and Saguinus labiatus), have suggested that they may also be susceptible to non-A, non-B hepatitis viruses $(117,118)$. However, these studies were undertaken before the non-A, non-B hepatitis virus group was identified and specific diagnostic tests for $\mathrm{HCV}$ were available. A recent study showed the lack of susceptibility of the cottontop tamarin (Saguinus oedi- pus oedipus) to HCV infection (119). We have investigated the susceptibility of rhesus monkeys to HCV infection $(120,121)$. Animals were inoculated intravenously with pooled HCV/RNA-positive plasma samples and the infection was widely monitored by biochemical, serological, histological and virological parameters for up to 70 days. The course of HCV infection was similar to that observed in the early acute phase of chimpanzee experimentally infected with $\mathrm{HCV}$ $(99,102)$. Specific HCV antigen and peculiar ultrastructural changes were seen in liver along with increased ALT levels and HCV RNA in serum samples. Although animals have been followed for a relatively short period, the results are encouraging in terms of more prolonged studies in the future.

\section{Hepatitis D virus (HDV)}

The host range for productive replication of HDV is limited to those species that support the replication of a hepadnavirus capable of supplying a helper function. These include the chimpanzee (coinfected with HBV) and the eastern woodchuck (coinfected with WHV).

Chimpanzees were shown to be susceptible to infection with HDV shortly after the discovery of the delta antigen $(23,122)$. Indeed, they were critical for the original identification of HDV as a distinct viral pathogen and since then have proved to be an invaluable source of information and material for the study of the biology and pathogenesis of HDV. However, only during the acute phase of infection does the chimpanzee model share some virological and histopathological features with humans. The acute phase may last for up to 7 months, with fluctuating serum ALT levels, and a pattern of immune response that is partially similar to that observed in humans: rising titers of total antibodies to HDAg (anti-HD) usually appear when ALT activities decrease (23), but antiHD IgM antibodies are only occasionally 
seen and low-titered (123). Persistent HDV infection has been documented in chimpanzee colonies at both the NIAID (123) and the Centers for Disease Control in Atlanta, GA, USA (124). Similar to humans, chronicity is much more likely a result from superinfection than from coinfection (123). However, chronic HDV in the chimpanzee is associated with only minor inflammatory changes, slightly altered ALT, and low levels of serum HDV RNA, while intrahepatic HDAg and IgM anti-HD are invariably absent $(123,125)$.

The chimpanzee model has helped to elucidate the mechanisms by which HDV is transmitted to HBV-susceptible individuals (coinfection) or to HBV carriers (superinfection) (126). It has also shown that the severity of the liver damage in the acute phase of infection is independent of the infectious dose (127) and correlates with passage number (125). A decrease in the incubation period and an increase in pathogenicity are observed with serial passages in chimpanzees (125). Characteristic cytoplasmic structures were also noted at the electron microscope level, similarly to those observed in human hepatitis C $(99,121)$. The chimpanzee model has also been an invaluable source of material for the molecular characterization of HDV RNA (128), and transfection experiments have been carried out by direct inoculation of a genomic-length complementary DNA (cDNA) clone of HDV in the liver of these animals (129). However, a chimpanzee model for HDV infection is limited not only because this species is en- dangered, but also because the features of the chronic HDV infection in chimpanzees are substantially different from those observed in humans. For these reasons, chimpanzees have been replaced in many instances by the eastern woodchuck. As with $\mathrm{HBV}$, the woodchuck has also proved to be a better model of the human disease associated with persistent infection with HDV, as well as for testing new antiviral agents (130).

\section{Conclusions}

The rationale underlying the use of nonhuman primates in biomedical studies is that the evolutionary proximity of monkeys to human beings permits the reproduction and study of human diseases that cannot be examined in animals other than monkeys. Hepatitis viruses represent one of the most striking examples of this situation. Interestingly, the first experimental infection studies in non-human primates were carried out when the causative viruses had not yet been identified and methods for specific diagnosis were unavailable. In fact, specimens obtained from infected monkeys have been crucial for achieving both of these goals, and these models still represent an invaluable tool for the study of these viruses and for testing vaccines and antiviral drugs. Nevertheless, the use of non-human primates for experimental purposes has been subjected to severe regulations and restrictions. For this reason, efforts should be made to find alternative primate species, and to establish efficient cell cultures. 


\section{References}

1. Alter HJ, Nakatsuji Y, Melponder J, Wages J , Wesley R \& Shih J W-R (1997). The incidence of transfusion-associated hepatitis $G$ virus infection and its relation to liver disease. New England J ournal of Medicine, 336: 741-746.

2. Gaspar AMC, Vitral CL, Yoshida CFT \& Schatzmayr HG (1992). Primary isolation of a Brazilian strain (HAF-203) of hepatitis $A$ virus in primate cell line (FRhK-4). Brazilian J oumal of Medical and Biological Research, 25: 697-705.

3. Gaspar AMC, Vitral CL, Yoshida CFT \& Schatzmayr HG (1993). Fast and high titre growth of a Brazilian hepatitis A virus (HAF-203) in primate cell line. Brazilian $J$ ournal of Medical and Biological Research, 26: 203-206.

4. Deinhardt $F$ (1976). Hepatitis in primates. Advances in Virus Research, 20: 113-157.

5. Hillis WD (1961). An outbreak of infectious hepatitis among chimpanzees handlers at a United States Air Force base. American J ournal of Hygiene, 73: 316328.

6. Deinhardt $F$, Courtois $G$, Dherte $P$, Osterrieth P, Ninane G, Henle G \& Henle W (1962). Studies of liver function tests in chimpanzees after inoculation with human infectious hepatitis virus. American J oumal of Hygiene, 75: 311-321.

7. Deinhardt F, Holmes AW, Capps RB \& Popper H (1967). Studies on the transmission of human viral hepatitis to marmoset monkeys. I. Transmission of disease, serial passages, and description of liver lesions. J oumal of Experimental Medicine, 125: 673-688.

8. Parks WP, Melnick J L, Voss WR, Singer DB, Rosengerb HS, Alcott J \& Casazza AM (1969). Characterization of marmoset hepatitis virus. J ournal of Infectious Diseases, 120: 548-559.

9. Holmes AW, Wolfe L, Rosenblate $\mathrm{H}$ \& Deinhardt F (1969). Hepatitis in marmosets: induction of disease with coded specimens from a human volunteer study. Science, 165: 816-817.

10. Dienstag J L, Feinstone SM, Purcell RH, Hoofnagle J H, Barker LF, London WT, Popper H, Peterson J M \& Kapikian AZ (1975). Experimental infection of chimpanzees with hepatitis A virus. J oumal of Infectious Diseases, 132: 532-545.

11. Prince AM (1968). An antigen detected in the blood during the incubation period of serum hepatitis. Proceedings of the National Academy of Sciences, USA, 60: 814-821.
12. Feinstone SM, Kapikian AZ \& Purcell RH (1973). Hepatitis A: detection by immune electron microscopy of a viruslike antigen associated with acute illness. Science, 182: 1026-1028.

13. Alter HJ , Purcell RH, Holland PV \& Popper H (1978). Transmissible agent in non-A, non-B hepatitis. Lancet, i: 459-463.

14. Tabor E, Gerety RJ , Drucker J A, Seeff LB, Hoofnagle J H, J akson DR, April M, Barker LF \& Pineda-Tamondong G (1978). Transmission of non-A, non-B hepatitis from man to chimpanzees. Lancet, i: 463-466.

15. Bradley DW, Cook EH, Maynard JE, McCaustland KA, Ebert J W, Dolana GH, Petzel RA, Kantor RJ , Heilbrunn A, Fields HA \& Purphy BL (1979). Experimental infection of chimpanzees with antihemophilic (factor VIII) materials. Recovery of virus-like particles associated with non-A, non-B hepatitis. J oumal of Medical Virology, 3: 253-269.

16. Choo Q-L, Kuo G, Weiner AJ , Overby LR, Bradley DW \& Houghton M (1989). Isolation of a cDNA clone derived from a bloodborne non-A, non-B viral hepatitis genome. Science, 244: 359-362.

17. Kuo G, Choo Q-L, Alter HJ , Gitnick GL, Redeker AG, Purcell RH, Miyamura T, Dienstag J L, Alter MJ, Stevens CE, Testmeier GE, Bonino F, Colombo M, Lu W-S, Kuo C, Berger K, Shuster J R, Overby LR, Bradley DW \& Houghton M (1989). An assay for circulating antibodies to a major etiologic virus of human non-A, nonB hepatitis. Science, 244: 362-364.

18. Tsukama H, Hiyama T, Tanaka S, Nakao M, Yabuuchi T, Kitamura T, Nakanishi K, Fujimoto I, Inove A, Yamazaki H \& Kawashima T (1993). Risk factor for hepatocellular carcinoma among patients with chronic liver disease. New England J ournal of Medicine, 328: 1797-1801.

19. Balayan MS, Andjaparidze AG, Savinskaya SS, Ketilaze ES, Braginsky DM, Savinov AP \& Poleschuk VF (1983). Evidence for a virus in non-A, non-B hepatitis transmitted via the fecal-oral route. Intervirology, 20: 23-31.

20. Reyes GR, Purdy MA, Kim JP, Savinov $A P$, Poleschuk VF, Luk K-C, Young LM, Fry KE \& Bradley DW (1990). Molecular cloning from the virus responsible for enterically transmitted non-A, non-B hepatitis. Science, 247: 1335-1339.

21. Favorov MO, Fields HA, Purdy MA, Yashina TL, Aleksandrou AG, Alter MJ, Yarasheva DM, Bradley DM \& Margolis HS (1992). Serologic identification of hepatitis $\mathrm{E}$ virus infections in epidemic and endemic settings. J ournal of Medical Virology, 36: 246-250.

22. Rizzetto M, Canese MG, Aricó S, Crivell O, Trepo C \& Verme G (1977). Immunofluorescence detection of a new antigen antibody system ( $\delta /$ anti- $\delta$ ) associated to the hepatitis $B$ virus in the liver and in the serum of HBsAg carriers. Gut, 18: 9971003.

23. Rizzetto M, Canese MG, Gerin J L, London WT, Sly DL \& Purcell RH (1980). Transmission of the hepatitis B virus-associated delta antigen to chimpanzees. J ournal of Infectious Diseases, 141: 590602.

24. Fonseca J OF \& Simonetti J P (1987). Epidemiology of the hepatitis delta virus (HDV) in Brazil. In: Rizzetto M, Gerin J L \& Purcell RH (Editors), The Hepatitis Delta Virus and its Infection. Alan R. Liss, New York, 507-514.

25. Rizzetto $M$, Bonino $F$, Verme G, Purcell RH \& Gerin J L (1983). Nomenclature: a proposal to designate the delta agent as hepatitis D virus. In: Rizzetto M, Gerin J L $\&$ Purcell RH (Editors), The Hepatitis Delta Virus and its Infection. Alan R. Liss, New York, xx-xxi.

26. Simons J N, Pilot-Matias TJ, Leary TP, Dawson GJ, Desai SM, Schlauder GG, Muerhoff AS, Erker JC, Buijk SL, Chalmers ML, VanSant CL \& Mushahwar IK (1995). Identification of two flaviviruslike genomes in the GB hepatitis agent. Proceedings of the National Academy of Sciences, USA, 92: 3401-3405.

27. Bukh J \& Apgar CL (1997). Five new or recently discovered (GBV-A) virus species are indigenous to New World monkeys and may constitute a separate genus of the Flaviviridae. Virology, 229: 429-436.

28. Leary TP, Muerhoff AS, Simons J N, PilotMatias TJ, Erker J C, Chalmers ML, Schlauder GG, Dawson GJ , Desai SM \& Mushahwar IK (1996). Sequence and genomic organization of GBV-C: A novel member of the Flaviviridae associated with human non-A-E hepatitis. J ournal of Medical Virology, 48: 60-67.

29. Linnen J , Wages J r J , ZhangKeck Z-Y, Fry $\mathrm{KE}$, Krawczynski K, Alter H, Koonin K, Gallagher M, Alter M, Hadziyannis S, Karayiannis $P$, Fung $K$, Nakatsuyi $Y$, Shih JWK, Young L, Piatak J r M, Hoover C, Fernandez J, Chen S, Zou J C, Morris T, Hyams KC, Ismay S, Lifson J D, Hess G, Foung $\mathrm{SKH}$, Thomas $\mathrm{H}$, Bradley $\mathrm{D}$, Margolis H \& Kim J P (1996). Molecular 
cloning and disease association of hepatitis $G$ virus: a transfusion-transmissible agent. Science, 271: 505-508.

30. Lampe E, Saback FL, Yoshida CFT \& Niel C (1997). Infection with GB virus C/Hepatitis $G$ virus in Brazilian hemodialysis and hepatitis patients and asymptomatic individuals. J ournal of Medical Virology, 52: 61-67.

31. Vitral CL, Yoshida CFT, Marchevsky RS, Pinto MA \& Gaspar AMC (1996). Experimental infection in squirrel monkeys with a Brazilian hepatitis A virus (HAF-203). In: Buisson $Y$, Coursaget $P \&$ Kane $M$ (Editors), Enterically-Transmitted Hepatitis Viruses. La Simarre, J oué-lès-Tours, France, 96-98.

32. Pillot J (1990). Les primates dans l'étude des virus des hépatites. Pathologie Biologie, 38: 177-181.

33. Vitral CL, Marchevsky RS, Yoshida CFT, Coelho JMCO, Gaspar AMC \& Schatzmayr HG (1995). Intragastric infection induced in marmosets (Callithrix jacchus) by a Brazilian hepatitis $A$ virus (HAF-203). Brazilian J ournal of Medical and Biological Research, 28: 313-321.

34. Gaspar AMC, Vitral CL, Marchevsky RS, Yoshida CFT \& Schatzmayr HG (1992). A Brazilian hepatitis $A$ virus isolated and adapted in primate and primate cell line as a chance for the development of a vaccine. Memórias do Instituto Oswaldo Cruz, 87: 449-450.

35. Prevot S, Marechal J, Pillot J \& Prevot J (1992). Relapsing hepatitis A in Saimiri monkeys experimentally reinfected with a wild type hepatitis A virus (HAV). Archives of Virology, 4 (Suppl): 5-10.

36. Lapin BA \& Shevtova ZV (1990). Persistence of spontaneous and experimental hepatitis $A$ in rhesus macaques. Experimental Pathology, 39: 59-60.

37. Karayiannis $P$, Chitranukroh $R$, Fry $M$, Petrovic LM, Moore D, Scheuer PJ \& Thomas HC (1990). Protracted alanine aminotransferase levels in tamarins infected with hepatitis A virus. J oumal of Medical Virology, 30: 151-158.

38. Baptista ML, Marchevsky RS, Oliveira AV, Yoshida CFT \& Schatzmayr HG (1993). Histopathological and immunohistochemical studies of hepatitis A virus infection in marmoset Callithrix jacchus. Experimental Toxicology and Pathology, 45: 7-13.

39. Keenan CM, Lemon SM, LeDuc JW, McNamee GA \& Binn LN (1984). Pathology of hepatitis $A$ infection in the owl monkey (Aotus trivirgatus). American J ournal of Pathology, 115: 1-8.
40. Karayiannis $P$, J owett $T$, Enticott $M$, Moore D, Pignatelli M, Brenes F, Scheuer PJ \& Thomas HC (1986). Hepatitis A virus replication in tamarins and host immune response in relation to pathogenesis of liver cell damage. J oumal of Medical Virology, 18: 261-276.

41. Asher LVS, Binn LN, Mensing TL, Marchwicki RH, Vassel RA \& Young GD (1995). Pathogenesis of hepatitis A in orally inoculated owl monkeys (Aotus trivirgatus). J oumal of Medical Virology, 47: 260-268.

42. Krawczynski KK, Bradley DW, Murphy BL, Ebert JW, Anderson TE, Doto IL, Nowoslawski A, Duermeyer W \& Maynard J E (1981). Pathogenetic aspects of hepatitis A virus infection in enterally inoculated marmosets. American J ournal of Clinical Pathology, 76: 698-706.

43. Karayiannis $P$, McGarvey MJ, Fry MA \& Thomas HC (1988). Detection of hepatitis A virus RNA in tissues and faeces of experimentally infected tamarins by cDNARNA hybridization. In: Zuckerman AJ (Editor), Viral Hepatitis and Liver Disease. Alan R. Liss, New York, 117-120.

44. Mathiesen LR, Drucker J, Lorenz D, Wagner J A, Gerety RJ \& Purcell RH (1978). Localization of hepatitis A antigen in marmoset organs during acute infection with hepatitis A virus. J ournal of Infectious Diseases, 138: 369-377.

45. Emerson SU, Lewis M, Govindarajan S, Shapiro M, Moskal T \& Purcell RH (1992). cDNA clone of hepatitis A virus encoding a virulent virus: induction of viral hepatitis by direct nucleic acid transfection of marmosets. J ournal of Virology, 66: 66496654.

46. Balayan MS (1992). Natural hosts of hepatitis A virus. Vaccine, 10 (Suppl 1): S27S31.

47. Emerson SU, Tsarev SA, Govindarajan S, Shapiro M \& Purcell RH (1996). A simian strain of HAV, AGM-27, functions as an attenuated vaccine for chimpanzees. J ournal of Infectious Diseases, 173: 592-597.

48. Shaffer DR, Emerson SU, Murphy PC, Govindarajan S \& Lemon SM (1995). A hepatitis $A$ virus deletion mutant which lacks the first pyrimidine-rich tract of the 5 'non translated RNA remains virulent in primates after direct intrahepatic nucleic acid transfection. J oumal of Virology, 69: 6600-6604.

49. Bradley DW, Gravelle CR, Cook EH, Fields RM \& Maynard JE (1977). Cyclic excretion of HAV in experimentally infected chimpanzees: biophysical characterization of the associated HAV particles. J oumal of Medical Virology, 1: 133-138.

50. Popper $H$, Dienstag J L, Feinstone $S M$, Alter HJ \& Purcell RH (1980). The pathology of viral hepatitis in chimpanzees. Virchows Archiv. A, Pathological Anatomy and Histology, 387: 91-106.

51. Cohen JI, Feinstone $M \&$ Purcell $R H$ (1989). Hepatitis A virus infection in a chimpanzee: duration of viremia and detection of virus in saliva and throat swabs. J oumal of Infectious Diseases, 160: 887890.

52. Traham CJ, LeDuc JW, Staley EC, Binn LN, Marchwick RH, Lemon SM, Keenan CM \& Bancroft WH (1987). Induced oral infection of the owl monkey (Aotus trivirgatus) with hepatitis A virus. Laboratory Animal Science, 37: 45-50.

53. Mathiesen LR, Moller AM, Purcell RH, London WT \& Feinstone SM (1980). Hepatitis $A$ virus in the liver and intestine of marmosets after oral inoculation. Infection and Immunity, 28: 45-48.

54. Purcell RH, D'Hondt E, Bradbury B, Emerson SU, Govindarajan S \& Binn L (1992). Inactivated hepatitis A vaccine: active and passive immunoprophylaxis in chimpanzees. Vaccine, 10: 148-151.

55. Robertson $B H$, J ia $X-Y$, Tian $H$, Margolis HS, Summers DF \& Ehrenfeld EE (1993). Antibody response to nonstructural proteins of hepatitis A virus following infection. J ournal of Medical Virology, 40: 7682.

56. Robertson BH, D'Hondt EH, Spelbring J, Tian $\mathrm{H}$, Krawczynski $\mathrm{K} \&$ Margolis HS (1994). Effect of postexposure vaccination in a chimpanzee model of hepatitis A infection. J ournal of Medical Virology, 43: 249-251.

57. D'Hondt E, Purcel RH, Emerson SU, Wong DC, Shapiro M \& Govindarajan S (1995). Efficacy of an inactivated hepatitis A vaccine in pre- and postexposure conditions in marmosets. J ournal of Infectious Diseases, 171 (Suppl 1): S40-S43.

58. Funkhouser AW, Kaychaudhuri G, Purcell RH, Govindarajan S, Elkins R \& Emerson SU (1996). Progress toward the development of a genetically engineered attenuated hepatitis $A$ virus vaccine. J ournal of Virology, 70: 7948-7957.

59. Bradley DW, Krawczynski K, Cook J r EH, McCaustland KA, Humpherey CD, Spelbring JE, Myint $H \&$ \& Maynard JE (1987). Enterically transmitted non-A, non$B$ hepatitis: serial passage of disease in cynomolgus macaques and tamarins and recovery of disease-associated 27- to 34$\mathrm{nm}$ viruslike particles. Proceedings of the National Academy of Sciences, USA, 84: 
6277-6281.

60. Ticehurst J, Rhodes J r LL, Krawczynski K, Asher LVS, Engler WF, Mensing TL, Caudil J D, Sjogren MH, Hoke CH, LeDuc J W, Bradley DW \& Binn LN (1992). Infection of owl monkeys (Aotus trivirgatus) and cynomolgus monkeys (Macaca fascicularis) with hepatitis $E$ virus from Mexico. Joumal of Infectious Diseases, 165: 835-845.

61. Tsarev SA, Tsareva TS, Emerson SU, Kapikian AZ, Ticehust J, London $W \&$ Purcell RH (1993). ELISA for antibody to hepatitis E virus (HEV) based on complete open reading frame-2 protein expressed in insect cells: idenfication of HEV infection in primates. J ournal of Infectious Diseases, 168: 369-378.

62. Krawczynski K \& Bradley DW (1989). Enterically transmitted non-A, non-B hepatitis: identification of virus-associated antigen in experimentally infected cynomolgus macaques. J ournal of Infectious Diseases, 159: 1042-1049.

63. Tsarev SA, Emerson SU, Tsareva TS, Yarbough PO, Levis M, Govindarajan S, Reyes GR, Shapiro M \& Purcell RH (1993). Variation in course of hepatitis $E$ in experimentally infected cynomolgus monkeys. J ournal of Infectious Diseases, 167: 13021306.

64. Longer CF, Denny SL, Caudell J D, Mielde TA, Asher LVS, Myint KSA, Huang CC, Engler WF, LeDuc JW, Binn LN \& Ticehurst J R (1993). Experimental hepatitis E: pathogenesis in cynomolgus macaques (Macaca fascicularis). J oumal of Infectious Diseases, 168: 602-609.

65. Nanda SK, Panda SK, Durgapa H \& J amell $S$ (1994). Detection of the negative strand of HEV RNA in the livers of experimentally infected hesus monkeys: evidence for viral replication. J oumal of Medical Virology, 42: 237-240.

66. Arankalle VA, Chadha MS, Chobe LP, Nair R \& Banerjee K (1995). Cross-challenge studies in rhesus monkeys employing different Indian isolates of hepatitis $E$ virus. J ournal of Medical Virology, 46: 358-363.

67. Tsarev SA, Tsareva TS, Emerson EU, Rippy MK, Zack P, Shapiro M \& Purcell $\mathrm{RH}$ (1995). Experimental hepatitis $\mathrm{E}$ in pregnant rhesus monkeys: failure to transmit hepatitis E virus (HEV) to offspring and evidence of naturally acquired antibodies to HEV. J ournal of Infectious Diseases, 172: 31-37.

68. Gupta H, Tandon BN, Sriramacharis S, J oshi YK \& lyenger B (1990). Animal transmission of enteric non-A, non-B hepatitis infection to Macaca mulatta by faecal-oral route. Indian J oumal of Medical Research, 91: 87-90.

69. Tsarev SA, Tsareva TS, Emerson SU, Yarbough PO, Legters LJ, Moskal T \& Purcell RH (1994). Infectivity titration of a prototype strain of hepatitis E virus in cynomolgus monkeys. J ournal of Medical Virology, 43: 135-142.

70. Uchida T, Suzuki K, lida F, Shikata T, Araki M, Ichikawa M, Rikihisa T, Mizuno K, Sce S \& Win KM (1991). Virulence of hepatitis E virus with serial passages to cynomolgus monkeys and identification of viremia. In: Hollinger FB, Lemon SM \& Margolis HS (Editors), Viral Hepatitis and Liver Disease. Williams \& Wilkins, Baltimore, 526-528.

71. Balayan MS (1991). Hepatitis E virus infection: historical perspectives, global epidemiology, and clinical features. In: Hollinger FB, Lemon SM \& Margolis HS (Editors), Viral Hepatitis and Liver Disease. Williams \& Wilkins, Baltimore, 498-501.

72. Ticehurst J (1991). Identification and characterization of hepatitis $E$ virus. In: Hollinger FB, Lemon SM \& Margolis HS (Editors), Viral Hepatitis and LiverDisease. Williams \& Wilkins, Baltimore, 501-513.

73. Purdy MA, McCaustland RA, Krawczynski K, Spelgring J , Reyes GR \& Bradley DW (1993). Preliminary evidence that a trpEHEV fusion protein protects cynomolgus macaques against challenge with wildtype hepatitis E virus (HEV). J oumal of Medical Virology, 41: 90-94.

74. Fuerst TR, Yarbough $P O$, Zhang $Y$, McAtee P, Tam A, Lifson J , McCaustland K, Spellbring J, Bradley D, Margolis HS, Francotti M, Garson N, Slaoui M, Prieels J O \& Krawczynski K (1996). Prevention of hepatitis $E$ using a novel ORF-2 subunit vaccine. In: Buisson $Y$, Coursaget $P \&$ Kane M (Editors), Enterically-Transmitted Hepatitis Viruses. La Simarre, J oué-lèsTours, France, 384-392.

75. Tsarev SA, Tsareva TS, Emerson SU, Govindarajan S, Shapiro M, Gerin J L \& Purcell RH (1994). Successful passive and active immunization of cynomolgus monkeys against hepatitis $\mathrm{E}$. Proceedings of the National Academy of Sciences, USA, 91: 10198-10202.

76. Eichberg J W \& Kalter SS (1980). Hepatitis $A$ and $B$ : serologic survey of human and nonhuman primate sera. Laboratory Animal Science, 30: 541-545.

77. Traquina $\mathrm{P}$, Morandi $\mathrm{M}$, Contomi $\mathrm{M} \&$ Van Nest G (1996). MF59 adjuvant enhances the antibody response to recombinant hepatitis $B$ surface antigen vaccine in primates. J ournal of Infectious Diseases,
174: 1168-1175.

78. Michaels MG, Lanford R, Demetris AJ, Chavez D, Brasky K, Fung J \& Starzl TE (1996). Lack of susceptibility of baboons to infection with HBV. Transplantation, 61 : 350-351.

79. Barker LF, Maynard JE, Purcell RH, Hoofnagle J H, Berquist KK, London WT, Gerety RJ \& Krushak DH (1975). Hepatitis $B$ virus infection in chimpanzees: titration of subtypes. Journal of Infectious Diseases, 132: 451-458.

80. Barker LF, Maynard JE, Purcell RH, Hoofnagle J H, Berquist KR \& London WT (1975). Viral hepatitis type B in experimental animals. American J ournal of Medical Sciences, 270: 189-195.

81. Tabor E, Purcell RH \& Gerety RJ (1993). Primate animal models and titered inocula for the study of human hepatitis $A$, hepatitis $B$, and non-A, non-B hepatitis. J ournal of Medical Primatology, 12: 305-318.

82. Thung SN, Gerber MA, Purcel RH, London WT, Mihalik KB \& Popper H (1991). Animal model of human disease: chimpanzees carriers of hepatitis B virus. American J oumal of Pathology, 3: 328332.

83. Yan RQ, Su J J, Huang DR, Gan YC, Yang C \& Huang GH (1996). Human hepatitis B virus and hepatocellular carcinoma. I. Experimental infection of tree shrews with HBV. J ournal of Cancer Research and Clinical Oncology, 122: 283-288.

84. Ge $Y$, Huang $\mathrm{G}-\mathrm{Y}$, J ie $\mathrm{C}$, Wang $\mathrm{S}-\mathrm{S}$, Huang D-C, Wei L, J iang Y-Z \& Li R-J (1991). Studies of experimental infection of Macaca assamensis with human hepatitis $B$ virus. In: Hollinger FB, Lemon SM \& Margolis HS (Editors), Viral Hepatitis and Liver Disease. Williams \& Wilkins, Baltimore, 301-303.

85. Marion PL, Trepo C, Matsubara K \& Prince PM (1991). Experimental models in hepadnavirus research. Report of a workshop. In: Hollinger FB, Lemon SM \& Margolis HS (Editors), Viral Hepatitis and Liver Disease. Williams \& Wilkins, Baltimore, 866-874.

86. Roggendorf $M \&$ \& Tolle TK (1995). The woodchuck: an animal model for hepatitis B infection in man. Intervirology, 38: 100112

87. Prince $A M$, Vnek J, Brotman $B$ Hashimoto N \& van den Ende MC (1978). Comparative evaluations of hepatitis $B$ vaccines in chimpanzees and in man. In: Vyas GN, Cohen SN \& Schmid R (Editors), Viral Hepatitis. Franklin Institute Press, Philadelphia, 507-523.

88. Schellekens $M$, di Reus A, Peetermans 
J H \& van Eerd PACM (1987). The protection of chimpanzees against hepatitis $B$ viral infection using a recombinant yeastderived hepatitis $B$ surface antigen. Postgraduate Medical J ournal, 63 (Suppl 2): 93-96.

89. Davis HJ, McCluskie MJ, Gerin JL \& Purcell RH (1996). DNA vaccine for hepatitis B: evidence for immunogenicity in chimpanzees and comparison with other vaccines. Proceedings of the National Academy of Sciences, USA, 93: 7213-7218.

90. Wahl M, Iwarson S, Snoy P \& Gerety R (1989). Failure of hepatitis $B$ immune globulin to protect against experimental infection in chimpanzees. J ournal of Hepatology, 9: 198-203.

91. Ogata N, Ostberg L, Ehrlich PH, Wong DC, Miller RH \& Purcell RH (1993). Marked prolonged incubation period of hepatitis $B$ in a chimpanzee passively immunized with a human monoclonal antibody to the a determinant of hepatitis $B$ surface antigen. Proceedings of the $\mathrm{Na}$ tional Academy of Sciences, USA, 90: 3014-3018.

92. Sawada H, Iwasa S, Nishimura O \& Kitano $\mathrm{K}$ (1995). Efficient production of anti-(HBV) antibodies and their neutralizing activity in chimpanzees. Applied Microbiology and Biotechnology, 43: 445-451.

93. Gallagher $\mathrm{M}$, Fields $\mathrm{HA}$, dela Torre $\mathrm{N}$, Ebert J W \& Krawczynski K (1991). Characterization of HBV 2 by experimental infection in primates. In: Hollinger FB, Lemon SM \& Margolis HS (Editors), Viral Hepatitis and Liver Disease. Williams \& Wilkins, Baltimore, 227-229.

94. Ogata N, Zanetti AR, Yu M, Miller RH \& Purcell RH (1997). Infectivity and pathogenicity in chimpanzees of a surface gene mutant of hepatitis B virus that emerged in a vaccinated infant. J oumal of Infectious Diseases, 175: 511-523.

95. Ulrich PP, Bhat RA, Seto B, Mack D, Sninsky J \& Vyas GN (1989). Enzymatic amplification of HBV DNA in serum compared with infectivity testing in chimpanzees. J oumal of Infectious Diseases, 160: 37-43.

96. Negro $F$, Pacchioni $D$, Shimizu $Y$, Miller RH, Bussolati G, Purcell RH \& Bonino F (1992). Detection of intrahepatic replication of HCV RNA by in situ hybridization and comparison with histopathology. Proceedings of the National Academy of Sciences, USA, 89: 2247-2251.

97. Krawczynski K, Beach MJ, Bradley DW, Kuo G, DiBisceglie AM, Houghton $M$, Reyes GR, Kim J P, Choo Q-L \& Alter M (1992). Hepatitis $C$ virus antigen in hepa- tocytes: immunomorphologic detection and identification. Gastroenterology, 103: 622-629.

98. Lanford RE, Chavez D, Chisari FU \& Sureau C (1995). Lack of detection of negative-strand hepatitis C virus RNA in peripheral blood mononuclear cells and other extrahepatic tissues by the highly strand-specific rTth reverse transcriptase PCR. J oumal of Virology, 69: 8079-8083.

99. Shimizu YK, Weiner AJ, Rosenblatt J, Wong DC, Shapiro M, Popkin T, Houghton M, Alter HJ \& Purcell RH (1990). Early events in hepatitis $C$ virus infection in chimpanzees. Proceedings of the National Academy of Sciences, USA, 87: 64416444.

100. Beach MJ, Meeks EL, Mimms LT, Vallari D, DuCharme S, Spelbring J, Taskar S, Schleider JB, Krawczynski K \& Bradley DW (1992). Temporal relationship of HCV and antibody responses following experimental infection of chimpanzees. J ournal of Medical Virology, 36: 226-237.

101. Hilfenhaus J, Krupta U, Nowak T, Cummins $B$, Fuchs $K \&$ Roggendorf $M$ (1992). Follow-up of hepatitis $C$ virus infection in chimpanzees: determination of viremia and specific humoral immune response. J ournal of General Virology, 73: 1015-1019.

102. Farci $P$, Alter $H J$, Wong $D$, Miller RH, Shih J W, J ett B \& Purcell RH (1991). A longterm study of hepatitis $C$ replication in non-A, non-B hepatitis. New England J ournal of Medicine, 325: 98-104.

103. Abe K, Inchaupse G, Shikata T \& Prince AM (1992). Three different patterns of hepatitis $C$ virus infection in chimpanzees. Hepatology, 15: 690-695.

104. van Doom L-J, van Hoek K, de Martinoff G, Bosman F, Stuyver L, Kos T, Frantzen I, Sillekens P, Maertens G\& Quint W (1997). Serological and molecular analysis of hepatitis $C$ virus envelope regions 1 and 2 during acute and chronic infections in chimpanzees. J ournal of Medical Virology, 52: 441-450.

105. Muchmore E, Popper $H$, Peterson DA, Miller MF \& Lieberman HM (1988). Non-A non-B hepatitis-related hepatocellular carcinoma in a chimpanzee. J ournal of Medical Primatology, 17: 235-246.

106. Erickson AL, Houghton M, Choo Q-L, Weiner AJ, Dalston R, Muchmore E \& Walker CM (1993). Hepatitis C virus-specific CTL responses in the liver of chimpanzees with acute and chronic hepatitis C. J ournal of Immunology, 151: 41894199.

107. Weiner A, Erickson AL, Ransopon J,
Crawford K, Muchmore E, Hughes AL, Houghton M \& Walker C (1995). Persistent hepatitis $C$ virus infection in a chimpanzee is associated with emergence of a cytotoxic $\mathrm{T}$ lymphocyte escape variant. Proceedings of the National Academy of Sciences, USA, 92: 2755-2759.

108. Martell M, Esteban J I, Quer J, Genesca J, Weiner A, Esteban R, Guardia J \& Gomez J (1992). Hepatitis C virus (HCV) circulates as a population of different but closely related genomes: quasispecies nature of HCV genome distribution. J oumal of Virology, 66: 3225-3229.

109. Okamoto H, Kojima M, Okada S, Yoshizawa $H$, lizura $H$, Tanaka $T$, Muchmore EE, Peterson DA, Ito $Y \&$ Mishiro S (1992). Genetic drift of hepatitis $C$ virus during an 8.2-year infection in a chimpanzee: variability and stability. Virology, 190: 894-899.

110. Farci P, Alter HJ , Govindarajan S, Wong DC, Engle R, Lesniewski RR, Mushahwar IK, Desai SM, Miller RH, Ogata N \& Purcell RH (1992). Lack of protective immunity against reinfection with hepatitis $C$ virus. Science, 258: 135-140.

111. Okamoto H, Mishiro S, Tokita H, Tsuda F, Miyakawa Y \& Mayumi M (1994). Superinfection of chimpanzees carrying hepatitis $C$ virus of genotype $11 / 1 b$ with that of genotype $1 \mathrm{II} / 2 \mathrm{a}$ or $\mathrm{I} / \mathrm{la}$. Hepatology, 20: 1131-1136.

112. Choo Q-L, Kuo G, Ralston K, Weiner A, Chien D, VanNest G, Han J, Berger K, Thudium K, Kuo C, Kansopon J, McFarland J, Tabrizi A, Ching K, Moss B, Cummins LB, Houghton $M \&$ M Muchmore EE (1994). Vaccination of chimpanzees against infection by the hepatitis $C$ virus. Proceedings of the National Academy of Sciences, USA, 91: 1294-1298.

113. Koziel MJ \& Liang TL (1994). Vaccination against hepatitis $C$ virus infection: miles to go before we sleep. Hepatology, 20: 758-765.

114. Krawczynski K, Alter MJ , Tankersley DL, Beach M, Robertson BH, Lambert S, Kuo G, Spelbring J E, Muks E, Sinha S \& Carson DA (1996). Effect of immune globulin on the prevention of experimental hepatitis $C$ virus infection. J ournal of Infectious Diseases, 173: 822-828.

115. Yanagi M, Purcell RH, Emerson SU \& Bukh J (1997). Transcripts from a single full-length cDNA clone of hepatitis $C$ virus are infectious when directly transfected into the liver of a chimpanzee. Proceedings of the National Academy of Sciences, USA, 94: 8738-8743.

116. Kolyhalov AA, Agapov EV, Blight KJ, 
Mihali KK, Feinstone SM \& Rice CM (1997). Transmission of hepatitis C by intrahepatic inoculation with transcribed RNA. Science, 277: 570-574.

117. Karayiannis P, Scheuer PJ, Bamber M, Cohn D, Hum BAL \& Thomas HC (1983). Experimental infection of tamarins with human non-A, non-B hepatitis virus. J ournal of Medical Virology, 11: 251-256.

118. Watanabe T, Katagiri J, Kojima $\mathrm{H}$, Kamimura T, Ichida R, Ashida M, Hamada $C \&$ Shibayama T (1987). Studies on transmission of human non-A, non-B hepatitis to marmosets. J ournal of Medical Virology, 22: 143-156.

119. Garson J A, Whitby K, Watkins P \& Morgan AJ (1997). Lack of susceptibility of the cottontop tamarin to hepatitis $C$ infection. J oumal of Medical Virology, 52: 286288.

120. Vitral CL, Gaspar AMC, Marchevsky RS, Pinto MA, Silva MF, Pissumo JW, Barth OM, Alves VAF, Santos RTM, Vanderborght BOM, Lu M, Sarr S, Roggendorf M \& Yoshida CFT (1997). Evaluation of the susceptibility of rhesus monkeys for hepatitis $C$ virus infection. In: Rizzetto M, Purcell RH, Gerin JL \&
Verme G (Editors), Viral Hepatitis and Liver Disease. Edizioni Minerva Medica, Torino, Italy, 209-213.

121. Barth OM, Vitral CL, Côrtes LMC \& Yoshida CFT (1997). Ultrastructural aspects in liver of rhesus monkeys infected with hepatitis C virus (HCV). Acta Microscopica, 6 (Suppl 6): 456-457.

122. Rizzetto M, Hoyer B, Canese MG, Shih J W-K, Purcell RH \& Gerin J L (1980). Delta agent: the association of delta $(\delta)$ antigen with hepatitis B surface antigen and nuclei acid in the serum of delta infected chimpanzees. Proceedings of the National Academy of Sciences, USA, 77: 61246128.

123. Negro F, Bergmann KF \& Baroudy BM (1988). Chronic hepatitis D virus (HDV) infection in hepatitis B virus carrier chimpanzees experimentally superinfected with HDV. J ournal of Infectious Diseases, 158: 151-159.

124. Fields HA, Govindarajan S, Margolis HS, Schabke CD, Ebert JW \& Maynard JE (1986). Experimental transmission of the delta virus to a hepatitis $B$ chronic carrier chimpanzee with the development of persistent delta carriage. American J ournal of Pathology, 122: 308-314.

125. Ponzetto A, Negro F \& Popper H (1988). Serial passage of hepatitis delta virus in chronic hepatitis B virus carrier chimpanzees. Hepatology, 8: 1655-1661.

126. Purcell RH, Gerin J L, Rizzetto M, Ponzetto A, Bonino F \& London WT (1987). Experimental transmission of the delta agent to chimpanzees. In: Rizzetto M, Gerin J L \& Purcell RH (Editors), The Hepatitis Delta Virus and its Infection. Alan R. Liss, New York, 79-89.

127. Ponzetto A, Hoyer B, Popper H, Engle K Purcell RH \& Gerin J L (1987). Titration of the infectivity of hepatitis delta virus in chimpanzees. J oumal of Infectious Diseases, 155: 72-78.

128. Wang KS, Choo Q-L \& Weiner AJ (1986). Structure, sequence and expression of the hepatitis delta $(\delta)$ viral genome. Nature, 323: 508-514.

129. Sureau C, Taylor J \& Chao M (1989). Cloned hepatitis delta virus CDNA is infectious in the chimpanzee. J oumal of Virology, 63: 4294-4297.

130. Negro F (1996). Animal models of hepatitis delta virus infection. Viral Hepatitis Reviews, 2: 175-185. 